\title{
連続蒸解釜オーバーレイエ法の開発について*
}

\author{
タイイーメンテナンス株式会社 開発部 伊 藤 雅 章
}

\section{The Development of Stainless Steel Weld Overlaying for Continuous Digesters}

\author{
Masaaki Ito \\ Daio Maintenance Co., Ltd.
}

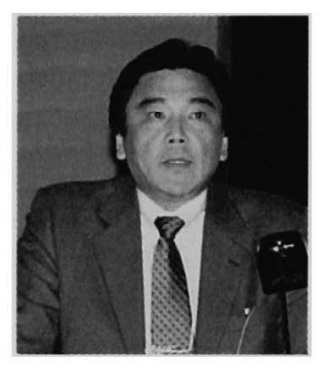

We have developed an overlay method for continuous digesters that substitutes the lining of stainless steel plates. We carried out the overlay $\left(110 \mathrm{~m}^{2}\right)$ at the NKP Continuous Digester in Daio Paper Co., Ltd. in March this year.

The superior points of our overlay method are the high welding quality achieved by using new automatic welding machines, the short term of the work and the high safety level for assembly, inspection and dismantling that employed an automatic scaffolding system.

Our method of overlay is capable of preventing corrosion of the welded parts that stainless steel lining plates have and corrosion of the cladding of continuous digesters.

分類 : F 2 KP 蒸解, F KP 製造一般（アルカリパルプ含む）

\section{1.はじめに}

今まで国内では炭素鋼で製作された連続蒸解釜は薬 品及びチップによる腐食・摩耗により減肉が発生する ため, 延命化対策としてステンレスプレートによるラ イニングを寒施してきた。しかしステンレスブレート によるライニングは溶接部の腐食および熱応力による 亀裂が発生する可能性が高く，従来より改善が望まれ ていた。今回大王製紙株式会社の NKP 連続蒸解金の 延命化対策として国内の技術でステンレスの肉盛り溶 接（オーパーレイ）を開発し，今年 3 月に洗浄ソーン $110 \mathrm{~m}^{2}$ を施工した。今回このオーパーレイ施工実績 を紹介する。

\footnotetext{
?平成 14 年度年次大会講演（講演 No. D 5)
}

\section{2. オーバーレイエ法の開発}

\section{1 溶接方法の設計}

第一種圧力容器である連続蒸解釜は母材の肉厚設計 值以上での運転が必要であり, 使用圧力・温度・液質 などの操業条件下において素材強度の低下, および変 形を防ぐため, ステンレス溶接の母材への溶け込み深 さ，肉盛り厚みを最少レベルになるように設計した。

1) 溶接材料 SUS $309 \mathrm{~L}$

2）溶け込み深さ $0.5 \mathrm{~mm}$ 以下（溶接サンプルを 図 1, ウィビング溶接平面写真を図 2 に示す)

3) 肉盛り厚み $2 \sim 2.5 \mathrm{~mm}$

2.2 安定した溶接品質を得る自動溶接機の開発 今回, 安定したウィビングを得るために従来の溶接 技術を基礎に最新鋭となる立向きウィビング自動溶接 機と数 $10 \mathrm{~mm}$ オーターの変位まで追従可能な倣い装 


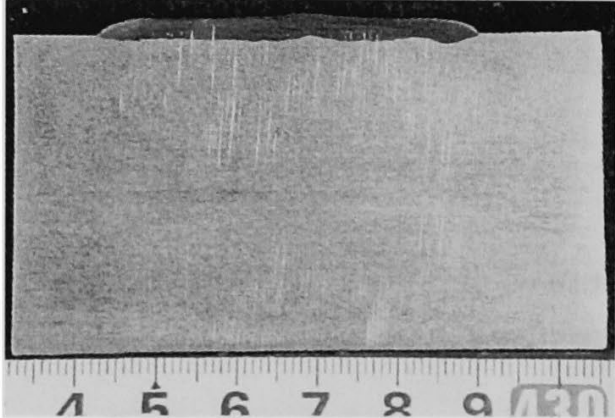

図 1 溶接サンプル断面

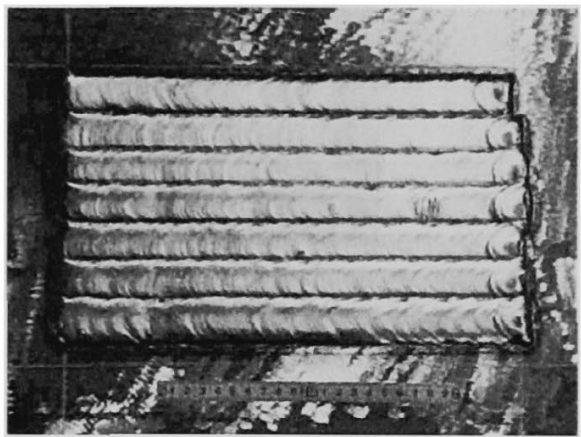

図 2 ウィビング溶接平面写真

表 1 測定要領

\begin{tabular}{c|c}
\hline 硬度計 & $\begin{array}{c}\text { 明石製作所 } \\
\text { ビッカース硬度計 }\end{array}$ \\
\hline 荷 重 & $2 \mathrm{~kg}$ \\
\hline 測定ポイント & 15 \\
\hline ピッチ & 压痕の対角舆さの4 倍 \\
\hline
\end{tabular}

置（トーチと素材の位置関係を一定にする）を開発し、 実際の連続蒸解釜の径に合わせた素材で溶接テストを 練り返し実施し，品質磼立を行った

1）熱影響による硬度変化について

表 1 に測定要領を，図3に測定個所を，図4 に測定 した結果をふす。溶接ボンド部より約 $2.24 \mathrm{~mm}$ 下よ り素材原質部と同等の硬度が得られたことから，熱影 翠部は溶接ボンド部から $2.0 \mathrm{~mm}$ 程度の僅かな深さに なっており，硬度值から考えても素材に与える影響は 問題ないことが判る。

2）溶接後の素材の機械的性質

肉盛りした素材（肉盛り部の境界）から採取したテ ストピースの㙨械的性質を表 2 に示す。またテストピ ースの採取要領を図 5 に示す。
肉盛部

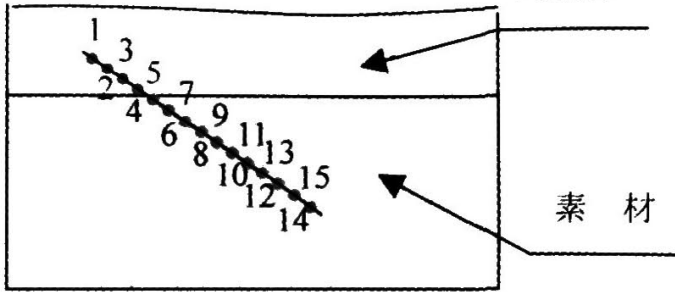

図 3

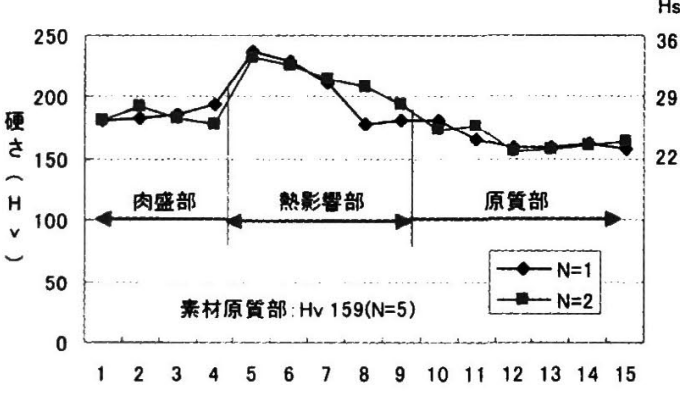

図 4 断面硬さ分布

表 2 溶接した素材の機械的性質

\begin{tabular}{c|c|c}
\hline \multirow{2}{*}{} & \multicolumn{2}{|c}{ 機械的性質 } \\
\cline { 2 - 3 } & $\begin{array}{c}\text { 引張強さ } \\
\left(\mathrm{N} / \mathrm{mm}^{2}\right)\end{array}$ & $\begin{array}{c}0.2 \% \text { 耐力 } \\
\left(\mathrm{N} / \mathrm{mm}^{2}\right)\end{array}$ \\
\hline 肉盛した素材 & 591 & 418 \\
\hline $\begin{array}{c}\text { 賟入材 } \\
\text { (ミルシート值) }\end{array}$ & 538 & 386 \\
\hline
\end{tabular}

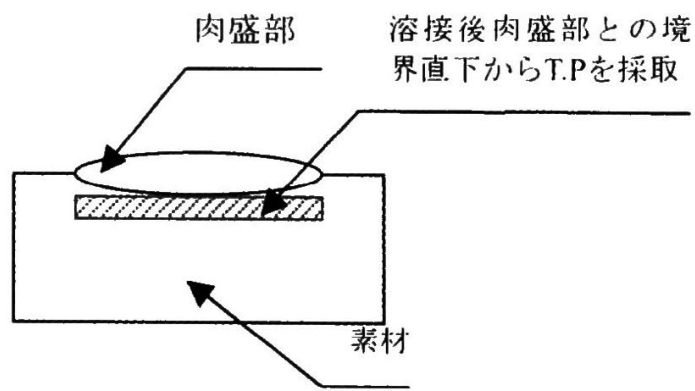

図 5 テストピース採取要領

表 2 からは肉盛りした素材の強度は元の素材と比較 して同等以上であり，溶接による素材の強度低下は認 められない。

3）溶接による残留応力の調査

連続蒸解釜の夙体部と同様の条件にするため，四隅 

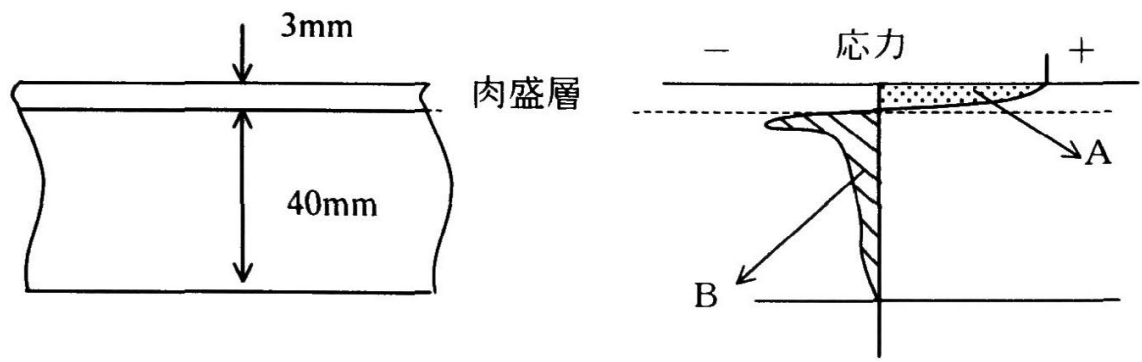

図 6 深さ方向残留応力分布

を拘束して肉盛り溶接したテストピースに歪みゲージ を取付し，表面と断面における開放歪みを測定した。

その結果, 肉盛り層と母材にかかる応力分布面積は 等しくなり, 実機で問題となる昰みは発生しないこと が判った（図6)。

\section{3. 今回オーバーレイ施工にあたり最大限}

重視した開発ポイント

連続蒸解釜の胴体部オーバーレイ施工にあたり当社 が開発過程で最大限にポイントをおいた点は以下の項 目である。

1）生産性を考え，施工工期を最大限に短縮する。

（1）連続蒸解釜の内径に合わせた自動年降式ステー ジを開発し、オーバーレイ装置の組立・解体、溶 接面の検查・補修を短時間で施工 (図 7, 図 8)。

2) 1 回当たり高さ $3 \mathrm{~m}$ まで施工できる自動溶接装 置開発と当該設備の配置替え時間を短時間で施工 できるように開発。

上記の工法により溶接スピードに制約される自動溶 接以外の作業は最大限に短縮が可能となり, 今年 3 月 に $110 \mathrm{~m}$ （高さ $6 \mathrm{mH} ）$ 施工した実績では連続蒸解釜 高圧洗浄後より 142 時間でオーバーレイを施亡完らし た。今後この工期は溶接スピードアッフと溶接仕上げ 作業の軽减を目的とした自動溶接機の改良によりさら に短縮できる見込みである。

2）作業の安全性を確保する

今まで鋼管材または丸太にて連続蒸解釜内に足場を 組み立てていたが, 修理点検作業では昇降に労力を有 するとともに，足場の強度の問題と転落の危険性を有 していた。当社では昨年 9 月より連続蒸解鉒専用に自 動昇降式ステージをメーカーと協同開発し, 転落の危 険性がなく動力で昇降し, 全面の洗浄・修理・点検・ 一圧検査ができるようにした。この自動昇降式ステー ジは, どのサイスの連続蒸解釜にも適用可能であり， 高い安全性を確保し，定期修理の工期短縮に効果を表 している。

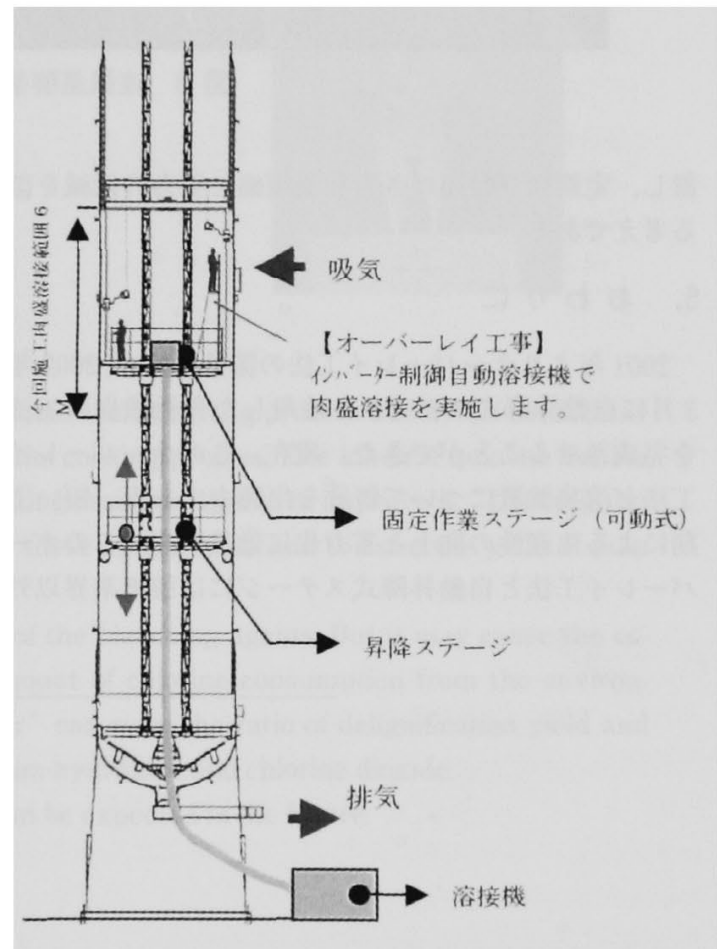

図 7 連続蒸解釜オーパレイ施「、概要図

\section{4. 今後の技術展開について}

今回施工したSUS $309 \mathrm{~L}$ オーバーレイを 2002 年 9 月に表面状態と摩耗状況に異常のないことを検証した。 また運転条件にもよるが, SUS 304 L クラッド鋼も海 外の技術資料では年間約 $0.43 \mathrm{~mm}$ 摩耗すると報告さ れている。

今後さらに摩耗・耐食に優れた溶接材料を開発し, クラット鋼も含めた連続蒸解釜の減肉を最小限にし, 設備の延命化を進める。

また自動昇降式ステージの機能を活用し，ステンレ スプレートによるライニング溶接線の点検・修理だけ でなく自動洗浄装置の設置および自動肉厚測定器を設 


伊藤雅章
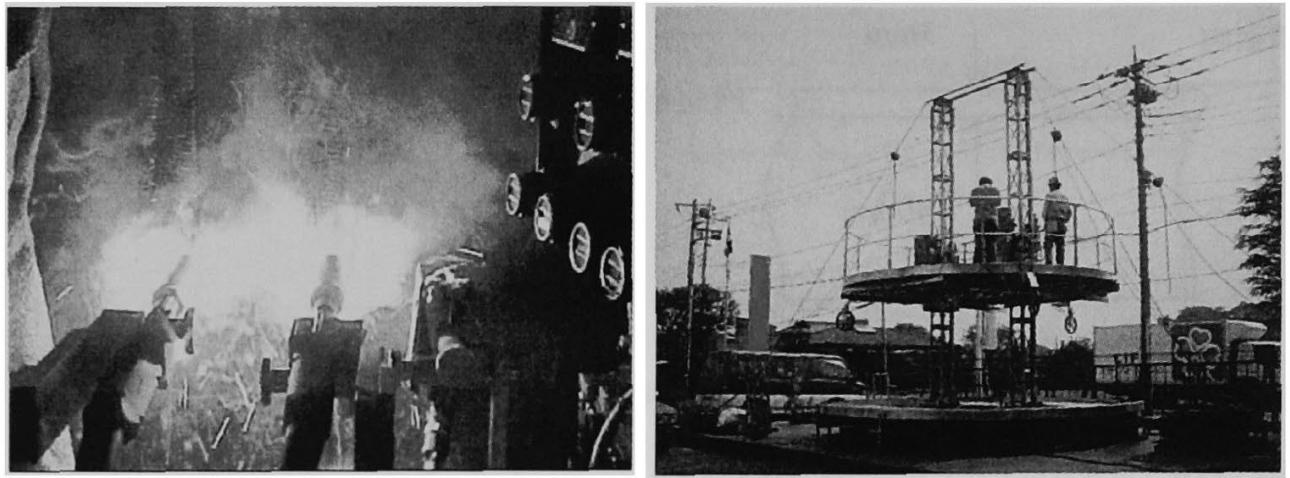

図 8 連続蒸解釜オーバレイ施工状況

置し，定期修理時間のさらなる短縮と労力の低減を図 る考えである。

\section{5. おわりに}

2001 年よりオーバーレイ工法の開発を始め, 2002 年 3 月に自動昇降式ステージを使用した当社独自の丁法 を完成させることができた。現在，このオーバーレイ 工法と溶接装置について特許を出願中である。短い工 期による生産性の向上と省力化に効果が高いこのオー バーレイ工法と自動昇降式ステージには製紙業界以外
からも多くの問い合わせがあり，数件の導入計画を進 めているところである。

今後さらに耐摩耗・耐腐食性の高い材料を開発し， 国内の連続蒸解釜の延命化に役に立てるよう鋭意努力 していく所存である。

最後に，装置の指導および施工を受け入れていただ いた大王製紙株式会社と技術開発に協力いただいた日 鉄ハード㑣の方々に紙面を借りて厚くお礼申し上げま す。 


\section{報 文 既 要 一 筧}

\section{連続蒸解金オーバーレイエ法の開発について}

ダイオーメンテナンス株式会社 開発部 伊藤 雅童

今まで国内では炭素銅で製作された連続蒸解釜は桼品及びチッブによる腐食・摩耗により減肉が発生 するため，延命化対策としてステンレスブレートによるライニングを実施してきた。しかしステンレス プレートによるライニングは溶接部の腐食および焦応力による笠が発生する可能性が高く，従来より 改善が望まれていた。今回大王製紙株式会社の NKP 連続蒸解釜の延命化対策として肉盛溶接（オーバ ーレイ）を当社と日铁ハード㮫で協同開発し, 2002 年 3 月に洗浄ソーン $110 \mathrm{~m}^{2}$ を施工した。当社のオー バーレイエ法の特㣲は以下の 2 点である。

(1) 施工工期を最大限に短縮

自助昇降式ステージを使用することで，オーバーレイ装置の組立・解体，溶接面の検査が短時間で 施工可能となった。

(2) 高い作菜安全性を確保

従来の銅管材，丸太による足場に比べ，転落の危険性がなく動力で昇降できる自動昇降式ステーシ により安全に連続蒸解釜内全面の洗浄・修理・点検が可能となった。

今後, 従来の SUS 304 L クラッド釾の摩耗にも対応できる溶接材料も開発し，安全に，短い工期で国 内の製林会社に連続蒸解釜の延命化対策を提供していく。

(本文 51 ページ)

\section{クラフトパルプ工程用新規薬剤}

サンノブコ株式会社 研究棯括部 吉内 圭吾

クラフト法は非常に優れたバルプ製造方法であるが，最大の久点は，蒸解によるパルプの収率が低 いことである。この久点を改善すべく，アントラキノン誘幕体やボリサルファイド系の化合物がパルフ の収率向上菜郕 (蒸解助剂) として幅広く使用されている。“蒸解促進剤”は, これら蒸解助剂の優れ た機能を促進する来郕であり，使用することによりパルプの収車をさらに上げることができる。また， 蒸解助郕はリグニンの分解作用も有するため，本蒸解促進剤の使用によりパルプのカッパー価をさらに 低下させることもできる。

蒸解後の漂白方法には多段漂白法が採用されており，中でも酸素漂白工程と晒工程を採用している所 が大半を占めている。唒工程では，堭素が主な漂白薬品として使用されているが，この使用はタイオキ シン発生の原因となりうろため, 環境問題の钼点からみると, 今後は塩素の使用量を娍少させていくこ とか好ましい。“酸素漂白促進郕”は，酸素漂白工程における漂白性を向上，すなわち脱りダニン事を 向上させる莱剂である。これにより，塩素のみならず，苛性ソータ，二酸化㙁素など，唒工程で使用さ れている漂白省品の消量を娍少させることができる。さらに，この奻果発現に伴い，晒工程から排出 される排水中の全有機物塩素化合物旦の低下による排水処理费用低娍奻果も期待される。

これらはいずれもクラフト法において有用であり，将来が期待される萂詴である。

(本文 55 ベージ) 